\title{
La CNT en el movimiento de octubre de 1934: entre el boicot y la par- ticipación*
}

\section{Ángel Herrerín UNED}

RESUMEN: La historiografía española ha prestado una especial atención a la actuación de los socialistas en el levantamiento de octubre de 1934, no en vano fueron los principales responsables de su organización. Sin embargo, el éxito necesitaba la participación de la otra gran organización de masas: la CNT (Confederación Nacional del Trabajo). Circunstancia que, salvo en el caso de Asturias, no se produjo. El presente trabajo trata de analizar las causas que llevaron al sindicato confederal a inhibirse e incluso oponerse a este movimiento. Para responder a esta cuestión es fundamental aproximarse a la visión que del levantamiento y de sus organizadores tenían los responsables libertarios. Para ello, ha sido imprescindible la consulta de forma exhaustiva de los documentos emanados por la propia organización y la documentación oficial de las Comandancias de la Guardia civil y del Ejército.

\section{Palabras Clave: Anarquismo; CNT; UGT; revolución; octubre;} 1934.

\section{The CNT in the October 1934 movement. Between the Boycott and the Participation}

ABSTRACT: Spanish historiography has focused on the socialist's attitude at the uprising of October 1934, considering that they were the principal responsible of its organization. However, the triumph needs to count with the participation of other big mass organization: the CNT (Labour National Confederation). This circumstance did not take place, exception made for the Asturias case. This paper analyzes the causes that explain why the

* Quiero agradecer a los evaluadores de la revista su atenta lectura del artículo, sus comentarios y sus acertadas recomendaciones que han contribuido a mejorarlo. La responsabilidad sobre el contenido del artículo, sin embargo, es mía. 
Confederal labor union inhibited itself and even took position against this movement. For answering to this question it is essential to analyze the vision that libertarians leaders had about the uprising and their organizers. This article is based on an exhaustive review of the documents produced by the CNT organization and the official documentation of the Guardia Civil and the Spanish Army.

KEY WORDS: Anarchism; CNT; UGT; revolution; October; 1934.

\section{INTRODUCCIÓN}

La CNT comenzaba el año de 1934 de una forma que se había convertido en habitual para la organización: locales cerrados, sindicatos clausurados, prensa prohibida y miles de militantes encarcelados. Lo que no impedía que siguiera con las mismas ansias revolucionarias que había mostrado en el bienio republicano socialista. Por su parte, la UGT iniciaba un camino muy diferente al que había transitado desde la proclamación de la II República. Los socialistas no habían podido alcanzar su sociedad ideal desde el gobierno, y en sus organizaciones soplaban también vientos revolucionarios. A pesar de que ambas organizaciones invocaban la necesidad de luchar por una sociedad más igualitaria, sus direcciones mostraban todo tipo de recelos para iniciar un diálogo que les permitiera unificar objetivos y conseguir la unidad de acción. De hecho, los socialistas comenzaron los preparativos de un levantamiento que pretendían protagonizar en solitario. El detonante fue la entrada de representantes de la CEDA en el gobierno republicano en octubre de 1934.

Aunque la historiografía ha prestado una atención especial a la actuación de los socialistas en este movimiento, no en vano fueron los responsables de su organización, lo cierto es que su resultado estaba, en gran parte, condicionado por la participación de otras fuerzas políticas en la acción, con mención especial al otro gran sindicato de masas: la CNT. De hecho, el referente principal de octubre del 34 ha sido lo sucedido en Asturias, único lugar dónde los acontecimientos tomaron un carácter revolucionario. Lo que obliga a poner el acento en aquello que marcó la diferencia con lo acontecido en otros lugares de España, que no es otra cosa que la participación de la CNT, o si se prefiere la unidad de acción entre ugetistas y cenetistas, a los que se añadirían otras organizaciones de izquierdas.

En consecuencia, el presente artículo pretende señalar los hechos y analizar las causas que llevaron a la organización anarcosindicalista a mantener posiciones diferentes, cuando no encontradas, en el movimiento de octubre de 1934. Actuaciones que influyeron de forma significativa en la extensión y resultado de la acción. Para ello, ha sido imprescindible la consulta de documentación oficial, en buena parte inédita, tanto de las Comandancias de la 
Guardia civil y del Ejército, como de la propia CNT, sin olvidar los archivos personales de militantes cenetistas.

\section{ANTECEDENTES A OCTUBRE}

La situación internacional influyó de forma determinante en el viraje táctico socialista. Las democracias italiana y alemana habían visto crecer en su seno a partidos fascistas que habían terminado devorándolas. Circunstancia que estaba muy presente en España con el triunfo de las derechas en las elecciones de noviembre de 1933. Con especial atención a la CEDA, cuyo líder, Gil Robles, había señalado en la campaña electoral que la democracia no era para ellos «un fin, sino un medio para la conquista de un Estado nuevo», en el que el Parlamento, si no se sometía, lo harían desaparecer ${ }^{1}$. El nuevo año trajo más motivos de alerta: el canciller Dollfuss, en febrero de 1934, aplastaba al socialismo austriaco. Así que en el manifiesto que confeccionaron los socialistas ante el $1^{\circ}$ de Mayo, además de señalar «la amenaza terrorista de los Gobiernos de Roma, Viena y Berlín», mostraba su sentimiento de que la República había sido «desmantelada y corrompida» al caer en manos de las antiguas oligarquías, que habían apartado del poder «a aquellas fuerzas sociales sin cuya presencia permanente en las cimas del nuevo régimen no se concibe la República». Los socialistas acusaban el golpe de ver cómo eran apartados de los Jurados Mixtos y de las antiguas corporaciones municipales para ser sustituidos por otros afines a los partidos ganadores en las últimas elecciones. Así que, aunque defendían la celebración de esta jornada con movilizaciones pacíficas, advertían que nadie entendiera esta actitud como una renuncia a la violencia, pues mantenían su derecho «tan fuerte como el de gobernar, a oponer el alzamiento revolucionario a la más tenue perspectiva de ludibrio fascista» ${ }^{2}$.

Una violencia que no sólo podía venir como consecuencia del avance fascista, sino también de la situación en los campos y fábricas de España. La fuerte crisis económica se mezclaba con las denuncias de los trabajadores por la actuación de empresarios y terratenientes que no respetaban las bases de trabajo acordadas. A las denuncias de jornales de miseria «sin límite de horario» y despidos por tener carnet sindical, se añadían gritos de «tenemos hambre, mucha hambre $»^{3}$. Hasta los propios sindicatos confederales corroboraban que, en más de una ocasión, los obreros estaban tan exaltados que los propios

1 GIL PECHARROMÁN, 2006: 283.

2 El Socialista, 1 de mayo de 1934.

3 Boletín de la UGT, mayo 1934, en BIZCARRONDO, 2008: 104-105. 
comités tenían que «hacer de bomberos» para contenerlos ${ }^{4}$. Aunque a veces era imposible. Como sucedió con la huelga de campesinos promovida por la Federación Nacional de Trabajadores de la Tierra (FNTT), adscrita a la UGT, en junio de 1934. Los dirigentes ugetistas fueron incapaces de detener una huelga que era la expresión de la desesperación de los campesinos. Su fracaso implicó la anulación del turno de colocación y de las bases de trabajo acordadas, destitución de alcaldes, clausura de sindicatos y Casas del Pueblo y la detención de entre 8.000 y 10.000 campesinos $^{5}$.

En la CNT llovía sobre mojado. A esta nueva represión se añadía la que venía sufriendo desde el inicio de la República, en gran medida, como respuesta a los movimientos insurreccionales que protagonizó. Aunque la historiografía siempre ha considerado que la CNT organizó tres levantamientos, en enero de 1932 y enero y diciembre de 1933, lo cierto es que esta aseveración necesita importantes matices. El primero de ellos no se puede considerar una insurrección de la CNT, pues no contó con la preparación ni la dirección del sindicato confederal. El levantamiento protagonizado por los mineros del Alto Llobregat y Cardoner fue una huelga local — por las malas condiciones de trabajo y la oposición de los patronos a respetar los derechos de reunión y asociación recogidos en la legislación republicana - ${ }^{6}$, que derivó en un levantamiento insurreccional sin tan siquiera el conocimiento de la dirección regional de la $\mathrm{CNT}^{7}$. El gobierno envió al ejército que controló la situación en pocos días. La represión incluyó la detención de más de un centenar de militantes cenetistas, alguno de los cuales no habían participado en la acción, y su embarque en el vapor Buenos Aires para su deportación a los dominios españoles en África. Entre los detenidos había personajes tan conocidos como Buenaventura Durruti o los hermanos Francisco y Domingo Ascaso. Esta circunstancia influyó en el devenir del sindicato confederal. Los anarquistas vieron la posibilidad de utilizar los acontecimientos para apartar de la dirección a los anarcosindicalistas. Federica Montseny, en un artículo incendiario titulado «Yo acuso» (como el famoso artículo de Émile Zola en el caso Dreyfus), culpaba a Ángel Pestaña, secretario general de la CNT, y a Emilio Mira, secretario de la regional catalana, del fracaso de la revolución y de las deportaciones a África, al tiempo que, sin ningún tipo de prueba, se preguntaba qué tipo de «enchufe, sinecura, qué ventajoso empleo,... qué diputación, ministerio...»les habían prometido para traicionar al movimiento ${ }^{8}$. La presión dio sus frutos: los faístas Manuel Rivas y Alejandro Gilabert sustituyeron a Pestaña y Mira

\footnotetext{
4 Boletín de la Región Galaica, abril-mayo 1934.

5 BIZCARRONDO, 2008: 110-113.

6 BORDERÍAS, 24-25 (Madrid, 1983): 187-199.

7 Acta Federación Local de Barcelona, enero 1932, IIHS, CNT, 93 B.

8 El Luchador, 19 de febrero de 1932.
} 
al frente de ambas secretarías. A finales de año, los faístas controlaban, prácticamente, la organización, mientras que los derrotados constituían los Sindicatos de Oposición 9 .

En cuanto a la insurrección de enero de 1933, la CNT terminó negando su convocatoria. La organización reunida en pleno había decidido apoyar la huelga de ferroviarios con el objetivo de hacerla derivar hacia un movimiento insurreccional, porque, según los delegados, había síntomas inequívocos de que la situación en el país era "francamente revolucionaria» ${ }^{10}$. Pero la realidad distaba mucho de esta apreciación. Los ferroviarios, afiliados en su mayoría a la UGT, apostaron por la negociación, así que la CNT desautorizó la lucha. Lo que no fue óbice para que la FAI se lanzara a la calle provocando el desconcierto en las filas cenetistas, que se creían convocados por su organización, lo que obligó a los periódicos confederales CNT y Solidaridad Obrera a desautorizar el movimiento ${ }^{11}$. En fin, que el sindicato se desvinculaba de la insurrección mientras que la FAI la hacía suya. El fracaso y la consiguiente represión incluyeron el encarcelamiento de un buen número de militantes, el cierre de los sindicatos y la prohibición de su prensa. En mitad del desastre, la dirección, en lugar de hacer autocrítica del camino emprendido, centraba sus protestas en la represión sufrida, con especial atención a los sucesos de Casas Viejas $^{12}$. El movimiento libertario volvía a poner en marcha lo que he denominado la «propaganda por la represión», término que ya he utilizado para referirme a las actuaciones de los anarquistas a finales del siglo XIX ${ }^{13}$. Ahora, en tiempos de la II República, la CNT, ante el fracaso cosechado por la vía insurreccional, ponía el énfasis en la represión sufrida. Así que en los plenos, además de culpar a los socialistas por ser «los responsables de todo», proponían la edición de folletos que contaran «el gesto heroico del camarada Seisdedos de Casas Viejas, como elemento de agitación que daría un resultado formidable a favor de la causa de los presos» ${ }^{14}$.

En la insurrección de diciembre, la CNT protagonizó, sin rodeos, la insurrección más importante en tiempos republicanos. Aunque volvía a partir de una premisa equivocada. Tras la importante abstención en las elecciones generales se pensaba, como «criterio irrefutable», que tras la victoria de las derechas los hombres de izquierda «se sumarían al movimiento revolucionario».

9 ELORZA, 1973: 454. Sobre anarquistas y anarcosindicalistas véase también PANIAGUA, 1982.

10 Actas Pleno de Regionales de CNT, Madrid, 2 de diciembre de 1932, IIHS, sig. CNT, 93 B.

11 Informe del Comité Regional de Levante sobre enero de 1933, CDMHS, sig. F-1511.

12 Las fuerzas del orden prendieron fuego a una casa con ocho miembros de una familia en su interior, de los que murieron seis, fusilaron a otros catorce campesinos y detuvieron a varias decenas, que denunciaron torturas. RAMOS, 2012.

13 HERRERÍN, 2011: 185-186.

14 Actas Pleno Nacional de Regionales, Madrid, 30 de enero de 1933, IIHS, sig. CNT, 93 B. 
Pero una cosa era no ir a votar y otra muy diferente lanzarse a la insurrección. Así que la CNT volvió a protagonizar en solitario el nuevo levantamiento que, irremisiblemente, volvió a fracasar. Los delegados, dejándose arrastrar por el «ambiente revolucionario» de los plenos, daban una interpretación de los acuerdos que no se correspondían con las decisiones tomadas en sus respectivas regionales. Así que mientras transmitían la predisposición de sus organizaciones a la acción, lo cierto era que la mayoría no lo estaban, lo que irremisiblemente les abocaba al fracaso. Esta acción fue la más cruenta pues en ella perdieron la vida 125 personas y hubo 186 heridos $^{15}$.

Las insurrecciones de 1933 supusieron un cambio importante en las actuaciones de la CNT que, ahora bajo control anarquista, restringía la lucha laboral «en holocausto al movimiento revolucionario» ${ }^{16}$. Sin embargo, estos movimientos no consiguieron su objetivo, en gran medida, porque se partía de planteamientos erróneos, como el supuesto momento revolucionario en el que, según señalaban, estaba permanentemente instalada la sociedad española. Pero también porque no contaban con el apoyo mayoritario de la población, ni siquiera de buena parte de los trabajadores. A este respecto es significativo el informe de la AIT sobre las insurrecciones, al señalar que «la falta más grave es que siempre se pulsa el ánimo de los militantes de la organización y nunca el estado de ánimo del pueblo» ${ }^{17}$. Además, estos movimientos no contaron con la organización ni los medios necesarios para conseguir su objetivo, como tampoco contaban con la colaboración de aquellos que tenían las armas necesarias para promover actos de estas características, como eran los militares. En definitiva, levantamientos que nunca tuvieron la mínima posibilidad de derribar la República, tanto por su falta de apoyo, preparación y medios, como porque, en todo momento, el gobierno actuó con contundencia y las fuerzas del orden permanecieron unidas en la represión.

Pero si los movimientos insurreccionales anarquistas no podían derrocar a la República, éstos y la consiguiente represión sí estuvieron a punto de acabar con la propia CNT. El comité nacional emitió un informe, a principios de 1934, en el que señalaba que organizaciones enteras estaban «completamente hundidas; Locales y Comarcales destrozadas...; clausurados los sindicatos gubernativamente y con una orden judicial... de disolución de la CNT... Éramos el Comité Nacional de una organización que por cien motivos distintos, estaba condenada a muerte... $\rangle^{18}$. Circunstancia que se reflejaba tanto en la

15 Actas del Pleno Nacional de Regionales, Barcelona, febrero de 1934, IIHS, sig. CNT, 93 B. ELORZA, 1973: 462-463. VILLA, 5 (Madrid, 2011): 177-205.

16 Actas Pleno Nacional de Regionales, Madrid, 12 de junio de 1933, IIHS, sig. CNT, 93 B.

17 Actas Pleno Nacional de Regionales, Madrid, junio de 1934, IIHS, sig. FAI, 36 B.

18 Informe Comité Nacional de CNT, 20 de enero de 1934, firmado el 26 de febrero de 1934, IIHS, sig. CNT, 93 B. 
drástica reducción de su afiliación — pérdida de medio millón entre finales de 1931 y enero de 193419 _, como en el número de militantes presos que, a principios de 1934, rondaba los $15.000^{20}$.

\section{EL INICIO DEL MOVIMIENTO DE OCTUBRE}

La entrada de la CEDA en el gobierno de la República fue la señal que los socialistas esperaban para el inicio de una huelga general que, en lugares como Asturias, derivó en un levantamiento insurreccional. Los preparativos venían de lejos. Ya a finales de enero de 1934, el PSOE, la UGT y las Juventudes Socialistas habían constituido una Comisión mixta que tenía como misión la organización del movimiento. Las directrices emanadas por el nuevo organismo señalaban, de forma especial, que el movimiento tenía que tener un protagonismo eminentemente socialista, evitando las alianzas con otras fuerzas, aunque admitiéndolas allí dónde la presencia socialista fuese minoritaria. El objetivo del movimiento, según la comisión, no era otro que la conquista del poder político mediante una insurrección armada. Para lo cual, las organizaciones socialistas formarían unas milicias e intentarían incorporar al movimiento a miembros de las fuerzas armadas ${ }^{21}$.

Pero el levantamiento contaría con la oposición de la dirección de la otra organización de masas que era necesaria para un movimiento de estas características: la CNT. En primer lugar, porque los anarquistas no creían en la conversión revolucionaria de los socialistas, a los que señalaban como traidores a la clase obrera y acusaban de ser los culpables de la situación por la que atravesaba la Confederación; $y$, en segundo lugar, porque el objetivo, además de difuso, parecía limitado a la toma del poder político y, por lo tanto, alejado de sus pretensiones. Ellos luchaban por la revolución social, y no estaban dispuestos a colaborar en un movimiento que tuviera como finalidad un simple cambio en la cúspide del poder.

Sin embargo, los militantes cenetistas se verían atrapados entre sus inquietudes revolucionarias y el recelo hacia los socialistas. Ya en febrero de 1934, la CNT se había dirigido a la UGT para que manifestase «clara y públicamente» cuáles eran sus aspiraciones revolucionarias; pero teniendo en cuenta que el emplazamiento era para la consecución de una auténtica revolución social y

19 ELORZA, 1973: 448-449. CASANOVA, 1997: 84.

20 Tiempos Nuevos, II/1, 10 de enero de 1935.

21 La comisión mixta estuvo formada por Juan Simeón Vidarte y Enrique de Francisco, del PSOE; Pascual Tomás y José Díaz Alor, por la UGT; y Carlos Hernández Zancajo y Santiago Carrillo, por las JJSS; el presidente fue Largo Caballero, en BIZCARRONDO, 2008: 115-117. 
no «un simple cambio de poderes, como el 14 de abril, si no a la supresión total del capitalismo y del Estado». Aunque los anarquistas, opositores a cualquier alianza, advertían de que no hacía falta la firma de documento alguno, bastaba con que la UGT se lanzara a la revolución en «la vía pública, campos y fábricas», pues allí encontraría a la $\mathrm{CNT}^{22}$. Así que cuando los socialistas se echaron a la calle en octubre del 34, la organización confederal se enfrentó a un gran dilema: apoyar un movimiento cuyo objetivo no compartía y que, además, estaba dirigido por aquellos que señalaban como principales culpables de la represión sufrida; o mantener una posición distante, que podía llegar al boicot, y faltar a la cita en la calle, donde pertinazmente convocaba a sus adversarios. Lo cierto es que en la actuación confederal hubo de todo.

De todas formas, aunque los socialistas no contaron en la mayoría de los casos con los cenetistas y ni siquiera les informaron, los militantes confederales no esperaron invitación alguna, ni siquiera directrices confederales, se lanzaron a la calle y participaron en el levantamiento. La solidaridad de clase se impuso a las reticencias y enfrentamientos de las direcciones. Así que no fue extraño que los cenetistas, a semejanza de insurrecciones anteriores, asaltaran ayuntamientos y proclamasen el comunismo libertario, como sucedió en Alcudia y en Banyeres (Alicante), en Villanueva (Cantabria) o en Aguilar del Campo (Valladolid) ${ }^{23}$. En algunos casos se notó la falta de sintonía entre ugetistas y cenetistas, como en el importante centro obrero de Alcoy (Alicante), donde el movimiento no se inició hasta el día 8, según señalaban los informes de la Comandancia de la Guardia civil, «debido al desconcierto que se produjo entre sindicalistas y socialistas en los primeros momentos». Aunque una vez superado, las hostilidades continuaron hasta el 12 de octubre ${ }^{24}$.

Las acciones se generalizaron a lo largo y ancho de la geografía española: en Cantabria, se proclamó la huelga general revolucionaria en la capital y provincia; en León, además de los levantamientos en la capital, 350 mineros de la zona de Santa Lucía de Gordón iniciaron una huelga que duró 15 días; en Ciudad Real hubo enfrentamientos en Corral de Calatrava, Campo de Criptana...; en Gerona, hubo levantamientos en Palamós y en Palafrugell; en las localidades jienenses de Linares, Martos, Torre Don Jimeno... se declaró la huelga general. En Ávila, en la madrugada del día 7, se cortaron los hilos del telégrafo; en Épila (Zaragoza) y Tarazona (Albacete), los insurrectos se apoderaron del ayuntamiento; en San Clodio (Lugo) hubo enfrentamientos

22 Acta Pleno Nacional de Regionales, Barcelona. Ponencia aprobada el 12 de febrero de 1934, IIHS, sig. CNT, 93 B.

${ }_{23}$ Memorias de las Comandancias de la Guardia civil de Alicante y Cantabria, AEHGC. Informes del 7 de octubre, AGMA, Antecedentes políticos, leg. 4, carp. 1.

${ }^{24}$ Memoria de la Comandancia de Alicante, AEHGC. 
entre los huelguistas y las fuerzas del orden...25. En el País Vasco, los socialistas, que eran mayoría, pretendieron realizar el levantamiento en solitario. Los cenetistas denunciaron que tuvieron varias entrevistas para participar en la acción, pero les negaron las armas ${ }^{26}$. En Bilbao, la huelga duró una semana. Hubo importantes enfrentamientos en Baracaldo, Portugalete, Sestao..., en Mondragón se proclamó la república socialista ${ }^{27}$.

En Levante, los enfrentamientos armados se extendieron por localidades como Elche, Alicante, Novelda, etc. En Valencia, se declaró la huelga general, que duró hasta el día $12^{28}$. En esta zona, la participación de los libertarios en el movimiento recayó en los Sindicatos de Oposición, incluidos en la Alianza Obrera constituida en la capital ${ }^{29}$. Aunque reconocieron sus limitaciones debido a que sólo hubo «una débil preparación en orden material y por tanto insuficiente para una acción de esa naturaleza» ${ }^{30}$. Por su parte, la CNT no participó y menospreció el movimiento señalando que la acción se había limitado a una huelga de 48 horas «que no pudo ser más inocente». Justificaba su pasividad por la falta real de una acción revolucionaria, y por qué el objetivo final era «la destrucción de la Confederación y del anarquismo» ${ }^{31}$. Así que, los Sindicatos de Oposición denunciaron la actitud de la CNT, pues mientras que a ellos les llamaban reformistas, los dirigentes confederales habían abandonado su puesto revolucionario y ocupado uno «al lado del enemigo». Ahora eran ellos los que entonaban «el 'Yo acuso' contra la CNT» —en referencia al señalado artículo de Federica Montseny ${ }^{32}$.

Otro lugar emblemático para la CNT era la regional de Aragón, Rioja y Navarra. No en vano el comité nacional de la organización residía en Zaragoza, y esta ciudad había sido el centro de la última insurrección anarquista. Los cenetistas de esta regional no tuvieron conocimiento de la acción hasta que se declaró la huelga general. Sin embargo, cuando los ugetistas comprobaron que ellos solos no podían realizar la acción mantuvieron contactos con los sindicatos confederales, pero la organización acordó mantenerse a la expectativa. En las otras capitales de la regional, Pamplona y Logroño, se declaró la huelga general. Pero los cenetistas, a semejanza de Zaragoza, se mantuvieron a la espera de recibir la orientación correspondiente. De todas formas, en Lo-

25 Informes de Comandancias, AEHGC. Noticias de las Comandancia, 7 de octubre; AGMA, Antecedentes políticos, leg. 4, carp. 1.

26 LORENZO, 1969: 69-70.

27 Informes, 7 de octubre, AGMA, Antecedentes políticos, leg. 4, carp. 1; RUIZ, 2008: 138-142.

28 Memoria Comandancias de Alicante y Castellón, AEHGC.

29 VEGA, 1987: 189-216.

30 El Combate Sindicalista, 27 de septiembre de 1935 y 18 de octubre de 1935.

31 Manifiesto de la CNT, enero 1935, IIHS, Fondo Ramón Álvarez, caja 444.

32 El Combate Sindicalista, 27 de septiembre de 1935. 
groño, los confederales solicitaron armas a los socialistas, que se las denegaron. Por lo que a las 48 horas de comenzar la huelga se dio por terminada. En Pamplona se repitieron las circunstancias, y la acción consistió, principalmente, en la convocatoria de huelgas pacíficas. Sin embargo, la situación fue diferente en las localidades más pequeñas, allí donde la solidaridad de clase se imponía a las decisiones de los comités responsables. En Uncastillo, socialistas y cenetistas se enfrentaron juntos a las fuerzas del orden; mientras que en Cervera del Río Alhama, los cenetistas, sin esperar consignas, se lanzaron a la lucha. Situaciones muy diferentes a las que se vivieron en Zaragoza, donde las relaciones entre socialistas y anarquistas eran de mutua desconfianza. Mientras que los primeros les apremiaban a participar y señalaban el éxito del levantamiento en comarcas enteras de Zaragoza, pero también en Madrid y Asturias; los segundos les requerían la confección de un documento que explicara claramente los objetivos del movimiento y el supuesto triunfo en los lugares señalados; condición a la que se negaron. Desconfianza que se incrementaba porque las noticias que recibían los cenetistas, sobre la situación en la capital de España y en la región asturiana, contradecían las afirmaciones de los socialistas.

En fin, el balance que la dirección aragonesa realizó del movimiento, que se podría aplicar a otras regiones, reconocía que los cenetistas se percataron de la magnitud del movimiento y se dirigieron al comité regional en busca de orientación. Pero éste, sin consignas por parte del comité nacional, les recomendó la espera. De todas formas, muchos militantes no pudieron sustraerse al ambiente, y la huelga general fue un hecho en la zona a excepción de Zaragoza, que se mantuvo a la expectativa. Esta circunstancia determinó la actuación de la regional, ya que lo que sucedía en la capital condicionaba, en gran medida, la acción del resto. Los pueblos, desorientados ante la falta de directrices, desistieron. La regional terminaba su informe poniendo en duda la actuación de la dirección confederal ${ }^{33}$.

Una actuación que, como es fácil de imaginar, estuvo marcada por lo acontecido en lugares tan importantes para el levantamiento, $y$ a dónde buena parte de España volvía su mirada, como eran Madrid y Barcelona.

\section{HUELGa Y BOICOT EN LA CAPITAL}

El 6 de octubre, el General Virgilio Cabanellas Ferrer, General de la $1^{\text {a }}$ División Orgánica, decretó el Estado de Guerra ${ }^{34}$. Era la respuesta a la importante huelga general que había comenzado el día de antes en la capital de Espa-

33 Informe Comité Regional de Aragón, Rioja y Navarra, febrero 1935, IIHS, CNT, 68 A.

${ }_{34}$ Bando del General Virgilio Cabanellas Ferrer, AGMA. Antecedentes políticos, leg. 2, carp. 1 . 
ña. Una huelga general que ha sido conceptuada como una de las más importantes en la historia de Madrid. Sin embargo, para que la huelga derivara en una insurrección que pusiera en peligro la estabilidad del régimen, faltó tanto el apoyo de las fuerzas armadas como la presencia y dirección de los dirigentes socialistas ${ }^{35}$, pero también la implicación de la CNT.

Al igual que había sucedido en las insurrecciones anarquistas, la ausencia de las fuerzas armadas junto a los huelguistas influyó decisivamente en el fracaso del movimiento. Los socialistas, como antes los anarquistas, mantuvieron contactos con mandos de las fuerzas armadas y realizaron propaganda para atraerse a los soldados, pero todos estos intentos cosecharon el más rotundo de los fracasos ${ }^{36}$. En cuanto a los líderes socialistas, simplemente no aparecieron. Mientras que los trabajadores ocupaban las calles y se batían con las fuerzas del orden, sus dirigentes esperaban a que los disturbios pasaran. El principal responsable del movimiento, Largo Caballero, realizó un periplo por diferentes domicilios de compañeros hasta ser detenido en su casa el día 14, es decir, más de una semana después de comenzar los disturbios ${ }^{37}$.

Respecto a la colaboración de la CNT, las diferencias entre socialistas y anarquistas impidieron cualquier acuerdo. El PSOE y la UGT eran fuerzas mayoritarias en la capital y, según las directrices emanadas por la comisión directiva, el movimiento lo comenzaron en solitario. De todas formas, los cenetistas madrileños reconocieron que estaban «al tanto de las actividades socialistas». Sabían lo que se estaba preparando, aunque desconocían la fecha exacta de la acción. Al día siguiente de la declaración de huelga, contactaron con el comité regional con la intención de negociar con la UGT y formalizar la participación de la CNT en los acontecimientos. Pero la dirección regional decía estar imposibilitada para tomar dicha decisión, así que se envió un delegado a Zaragoza para informar al comité nacional. El tiempo pasaba sin que la organización tomara ninguna resolución. Circunstancia que parecía incomprensible cuando había ya militantes cenetistas que se batían en las calles de Madrid y llegaban noticias de Asturias que hacían ver «que aquello era una revolución social».

El día 8 de octubre, es decir, tres días después de iniciada la huelga, el secretario general del comité nacional, Miguel Yoldi, llegaba a Madrid con la intención de realizar un pleno nacional para tomar una decisión. Intentar convocar un pleno en la situación reinante, con huelgas e insurrecciones en un buen número de ciudades y pueblos de España, con el objetivo de tomar la decisión de participar o no en el movimiento, muestra el grado de desconcierto de la organización. Como es fácil de imaginar, la convocatoria de un pleno

35 Véase: SOUTO, 2004. JULIÁ, 1984.

36 Consejos de guerra contra paisanos por incitación a la rebelión a militares de tropa, AGMS, caja 2637, Exp. 21106, secc. 9.

37 BIZCARRONDO, 2008: 129-130. RUIZ, 2008: 127-129. 
en estas circunstancias era misión imposible. Sólo pudieron asistir tres regionales: Levante, Aragón y Centro. Pero hasta esta última señalaba que no había conseguido ningún acuerdo de la organización sobre la cuestión a dilucidar y que, por lo tanto, no podía tomar ninguna decisión al respecto.

Ante la presencia de militantes cenetistas en las calles de Madrid, la dirección se vio obligada a hacer gestiones con los socialistas. Pero las negociaciones murieron antes de empezar, pues los socialistas ni siquiera acudieron a la cita concertada. A pesar de todo, militantes de Zaragoza presionaban al comité nacional para que se consultara a la organización sobre si se participaba e impulsaba el movimiento. Así que la dirección convocó un nuevo pleno que se celebró el día 14, en el que se acordó la no intervención de la CNT por ser ya tarde para tomar tal decisión ${ }^{38}$.

Pero quizá lo más importante de lo sucedido en Madrid sea la información que salió de la capital y que condicionó la toma de decisiones - o habría que decir la falta de decisiones - de la dirección confederal y, en consecuencia, la actuación de la CNT a nivel nacional. La organización decidió, en septiembre de 1934, la renovación de la redacción del periódico CNT de Madrid, para lo cual nombró director a Liberto Callejas, y redactores a Horacio Martínez Prieto, José Ballester y Juan García Oliver ${ }^{39}$. Pues bien, todo parece indicar que con la nueva redacción en su puesto y la huelga en marcha, las llamadas telefónicas desde el periódico influyeron en la toma de decisiones tanto del comité nacional, como de la regional catalana. Por lo menos eso es lo que denunció en su momento el comité revolucionario de Centro, que acusaba a García Oliver de engañar a la dirección de lo que estaba aconteciendo en Madrid. Según dicho comité la información aportada por Oliver no se ajustaba a la realidad al decir que algunos comercios estaban abiertos y circulaban algunos tranvías, cuando el paro era absoluto ${ }^{40}$.

Pero la denuncia iba mucho más lejos. El comité revolucionario celebró una reunión con los redactores y les invitó a integrarse en él, a lo que se negaron. Sus planteamientos eran muchos más radicales y, según sus palabras, no estaban dispuestos «a ser los guardias de asalto de los socialistas». Durante el encuentro, los miembros del comité observaron que desde el teléfono de la redacción se informaba de la situación en Madrid al comité nacional y a la organización catalana. De hecho, el comité nacional reconoció que el sábado 6 , en conferencia telefónica con la redacción, les habían informado «de que la huelga en Madrid era incompleta y desde luego sin importancia y de que en Asturias existían algunos focos que serían prontamente sofocados».

38 Informe Comité Regional de Centro y Pleno Regional, febrero de 1935, IIHS, CNT, 68 B. Informe Comité Regional de Aragón, Rioja y Navarra, febrero de 1935, IIHS, CNT, 68 A.

39 GARCÍA OLIVER, 2008: 215.

40 Actas Pleno de Locales y Comarcales de Centro, 25 de febrero de 1935, IIHS, CNT, 68 B. 
Un documento encabezado por los militantes madrileños Máximo Palomar, Feliciano Benito y Pedro Falomir acusaba a García Oliver, en primer lugar, de haber pretendido publicar CNT cuando la huelga era general en Madrid. Acusación que, según decían, estaba dispuesta a ratificar la camarada Lucía Sánchez de Saornil, que trabajaba también en la redacción del periódico; en segundo lugar, le acusaban de realizar una labor derrotista y contrarrevolucionaria, diciendo que «por todos los medios, había que hacer fracasar el movimiento», aseveración que podía ser corroborada por «centenares de camaradas de Madrid», entre otros: Angel Rodríguez, Serafín González y el resto de firmantes del documento que se presentaba; en tercer lugar, de haber informado falsamente al comité nacional y a la regional catalana señalando que la huelga era pacífica en Madrid y que en Asturias todo estaba sofocado; por último, le acusaban de haber influido en Miguel Yoldi para que anulara un telegrama que iba a enviarse a Zaragoza y cuyo texto decía: «Hermana grave, ponte en camino», que, según parece, apostaba por secundar el movimiento ${ }^{41}$.

En ambientes libertarios las críticas por la actuación de García Oliver fueron insistentes desde octubre del 34, con acusaciones que le señalaban como el responsable de frenar a la CNT para unirse al movimiento ${ }^{42}$. Así que la organización decidió nombrar una comisión para analizar lo sucedido. En las diligencias participaron los comités implicados, pero también militantes madrileños como la señalada Lucía Sánchez, que mediante una carta dijo no saber nada de lo que se pretendía, ya que los días antes del movimiento dejó de ir por la redacción. Otros mantuvieron la acusación, como Ángel Rodríguez, quien aseguró que estando con Falomir, Goméz, Prieto y Oliver, y tras un «altercado un tanto violento», éste último dijo que estaban «haciendo el juego a los socialistas, y que lo que había que hacer era dar la orden de vuelta al trabajo. Que el movimiento estaba planificado por los socialistas y que había que hacerlo fracasar». Rodríguez amplió sus denuncias a Martínez Prieto, que criticaba la actuación de la regional asturiana y apostaba por su expulsión cuando todo volviera a la normalidad. Cipriano Mera intervino en la comisión para decir que en la cárcel Feliciano Benito y González Mallada acusaban a Oliver de traicionar el movimiento, y que hasta un delegado de Vallehermoso le buscaba para matarlo por traición. Aunque también tuvo para el comité revolucionario, al señalar que los únicos que no supieron cumplir con su obligación fueron sus miembros.

En su defensa, García Oliver admitió que intentó sacar el diario en los primeros días de la insurrección «pero con la idea de fortificar el edificio y sacarlo violentamente a la calle»; también dijo que la frase de que iban a ser «los guardias de asalto de los socialistas» era más que justificada, sobre todo

41 Informe Comité Nacional de CNT, 22 de febrero de 1936, IIHS, CNT, 50 A.

42 GARCÍA OLIVER, 2008: 222. 
cuando Mundo Obrero, periódico comunista, había dicho en la víspera que ellos «no servirían de peones de brega a los socialistas». Pero el resto de las acusaciones las negó. Dijo que no informó de nada al comité nacional, ya que sólo habló con la redacción barcelonesa de Solidaridad Obrera, sin desestimar el movimiento. En cuanto a su comunicación con la regional catalana, señaló que su secretario general fue el que le telefoneó para ser informado de lo que sucedía en Madrid. Circunstancia que fue ratificada por Francisco Ascaso. Oliver le comunicó que había huelga general y que por la noche había oído fuertes tiroteos, sin poder precisar quién los provocaba. También negó que los redactores de CNT se pusieran al margen de la organización en Madrid, más bien al contrario, pues, según su versión, Martínez Prieto y él se ofrecieron a la federación local como militantes, pero les rechazaron arguyendo que ellos se debían al comité nacional y que su trabajo estaba en la redacción de $C N T$.

Por su parte, Martínez Prieto reconoció lo dicho sobre la regional asturiana, en gran medida, «por desconocer lo que pasó allí». Criticó su falta de disciplina, tanto en el pacto de la alianza como en el inicio de la lucha sin consultar con la dirección confederal. Aunque al final admitió «que como después se supo que la regional asturiana desconocía en absoluto los manejos socialistas», reconocía «su error» y rectificaba. Mientras que el otro redactor, José Ballester, admitió los rumores que circulaban en torno a que desde el periódico se influyó para que la regional catalana no interviniera en el movimiento. Reflexión que enlazaba con que mientras Mundo Obrero estaba clausurado, CNT salía normalmente; y que mientras que a los revolucionarios se les detenía, a los redactores confederales se les dejaba en libertad. De hecho, el propio Ballester advirtió que mientras que a él le detuvieron, al resto no les pasó nada.

La comisión terminó su labor sin pruebas concluyentes, sólo con la palabra de unos contra la de los otros. Así que en una CNT dirigida por faístas y teniendo en cuenta la importancia de elementos anarquistas como García Oliver o Francisco Ascaso, ambos miembros del influyente grupo Nosotros, en el que también militaba Durruti, la decisión de la organización difícilmente podía ser negativa para el acusado. En consecuencia, se dio por demostrado que toda la acusación era mentira, y aunque no faltaron los que, además, reclamaran una sanción para los acusadores, el comité nacional pidió «altura de miras» por haber actuado todos «con excesiva buena fe, aunque interpretando las cosas de forma distinta». En definitiva, se rehabilitó a García Oliver y no se adoptó ninguna medida contra los que se habían atrevido a mantener la acusación. Estos acuerdos se tomaron, significativamente, el 28 de diciembre de 1935, día de los Santos Inocentes. Aunque no se hicieron públicos hasta mucho más tarde, en concreto, el 22 de febrero de 1936, es decir, a los pocos días de la victoria del Frente Popular ${ }^{43}$. Momento en el que la alegría por el

\footnotetext{
43 Informe Comité Nacional de CNT, 22 de febrero de 1936, IIHS, CNT, 50 A.
} 
fin del gobierno de la derecha y la liberación de los presos abría perspectivas más halagüeñas. La nueva situación favorecía la táctica de olvidar «viejos» problemas y concentrarse en un futuro inminente que, una vez más, se presentía revolucionario.

Aunque más allá de la resolución que adoptó la organización, en el fondo de este asunto subyacía la importante división interna, pero también la diversidad que ha caracterizado al movimiento. Una diversidad que se desarrolló desde las primeras manifestaciones anarquistas en el siglo XIX, cuando se podía asegurar que existía «un anarquismo» para «cada zona, pero también para cada grupo y persona $\rangle^{44}$. Ahora existían diversas $\langle\mathrm{CNTs}$ » en cada localidad, comité o sindicato, cada una con una respuesta propia a los desafíos del momento. Aunque, con el ánimo de sintetizar para el asunto que nos ocupa, se pueden señalar dos grupos: por un lado, los críticos con la actuación básicamente insurreccional realizada desde la dirección de la organización, y que impulsaban un cambio de táctica que incluía la unidad de acción con la UGT. A este respecto, baste recordar que la regional de Centro era una de las que, junto a Asturias y Galicia, defendió la alianza obrera, en contra de la posición faísta. Por otro lado, estaban los anarquistas y faístas que ocupaban los puestos más relevantes de la organización y que no estaban dispuestos a apoyar una revolución que no era la suya y mucho menos si la protagonizaban los socialistas, responsables de agravios tantas veces repetidos. De hecho, la FAI señaló, una vez finalizado el levantamiento, que aquellos que habían participado lo hicieron de manera particular y sin el beneplácito de la organización ${ }^{45}$. Entre esos anarquistas contrarios al levantamiento se encontraba García Oliver que, según sus palabras, no estaba dispuesto a convertirse en el «guardia de asalto de los socialistas». A todo ello, habría que añadir, el menosprecio que sufrió por parte de éstos, al comunicarle personalmente, como admitió, que no querían su intervención. Datos suficientes para suponer la animadversión hacia un movimiento que consideraba contrario a la CNT y que podía atenuar simplemente con emitir una información ya no falsa, sino que escondiera toda la realidad.

Es evidente que la información sobre lo que estaba ocurriendo en Madrid era crucial para la actuación de la organización. Así lo entendía Falomir, que defendió hasta el final que la regional catalana ordenó la vuelta al trabajo por las informaciones que recibió de Madrid. A lo que habría que añadir lo que acontecía en Asturias, si tenemos en cuenta las declaraciones ante la comisión del propio Ascaso, quien reconoció que de haber sabido lo que sucedía en

44 HERRERÍN, 2011: 287. NAVARRO, 2013: 183-200.

45 Carta Comité Peninsular de FAI, Barcelona, al Comité de Relaciones de Grupos Anarquistas de Lengua Española en Francia, 27 de octubre de 1934, IIHS, Fondo FAI, sig. 4.1-18. 
aquella región, habrían ido a la revolución. Pero las circunstancias en las que se desenvolvió la organización catalana durante los días de octubre eran mucho más complejas.

\section{Cataluña: en la CAlle PERO CONTRA todos}

Las buenas relaciones entre la CNT y los dirigentes de Esquerra Republicana de Cataluña al inicio del nuevo régimen eran agua pasada en octubre del 34. En los primeros meses republicanos, la posición mayoritaria de la CNT en Cataluña y sus planteamientos federales ayudaron a que las preferencias de Francesc Macià, presidente de la Generalidad, se inclinaran por mantener unas buenas relaciones con la dirección confederal y dejaran en segundo plano a la UGT, más débil y centralista. De hecho, Macià se opuso a los decretos que preparaba el gobierno para reprimir a los cenetistas, en gran medida, porque, según señalaba Azaña, no quería «indisponerse con los sindicatos, de quienes espera votos para el referéndum del Estatuto» ${ }^{46}$. Efectivamente, la CNT no mostró ninguna oposición a que sus militantes participaran en dicha consulta ${ }^{47}$. Otros dirigentes catalanistas, como Joan Casanovas, regidor del Ayuntamiento de Barcelona, mantenía buenas relaciones con los confederales desde cuando los defendía ante los tribunales de justicia en tiempos de la monarquía ${ }^{48}$.

Pues bien todas estas relaciones sufrieron un cambio importante con la llegada de los faístas a la dirección de la CNT. Desde este momento, el enfrentamiento entre Esquerra y el sindicato confederal fue continuo. La prensa anarquista aireaba las acusaciones que desde $L$ 'Opinió, órgano vinculado a Esquerra, se lanzaban contra los anarquistas, a quienes se identificaba con «cuatro vividores» que imponían «una dictadura a la CNT» y que vivían de las cuotas de los trabajadores ${ }^{49}$; para responderles que eran los dirigentes catalanistas los que maltrataban a los compañeros detenidos acusándoles de atracadores cuando eran ellos: políticos, burgueses, banqueros, militares, los auténticos «Al Capones del erario y la hacienda» ${ }^{50}$. Así que los movimientos insurreccionales que los anarquistas protagonizaron en 1933 tuvieron la respuesta contundente ya no sólo del gobierno central, sino también de la Generalidad. En septiembre de 1934, 8.000 presos confederales se agolpaban en las cárceles catalanas ${ }^{51}$.

46 AZAÑA, 1981: 51.

47 LORENZO, 1969: 51. Sobre la división de la CNT en Cataluña, véase: VEGA, 1980.

48 AFSS, Fondo Frank Mintz, Informe Shapiro.

49 Tierra y Libertad, 77, 4 de noviembre de 1932.

50 FAI, 15 de mayo de 1934.

51 BRADEMAS, 1974: 144. 
Lluis Companys, presidente de Cataluña tras la muerte de Macià en la navidad de 1933, intentó profundizar en el autogobierno. Pero la ley de contratos de cultivos - que intentaba evitar la expulsión de los campos de los viticultores no propietarios de la tierra - aprobada en el parlamento catalán, supuso un choque con la administración central que culminó, gracias a la intervención de la CEDA, en la derrota del ejecutivo catalán ${ }^{52}$. Así que cuando el gobierno español incorporó a tres ministros cedistas, la Generalidad lo entendió como una declaración de guerra.

El movimiento libertario veía esta polémica con otros ojos. Al fin y al cabo era una visión esencialmente internacionalista que estaba a favor de derribar fronteras y en contra de singularidades nacionalistas. Así lo señalaba el editorial de Tierra y Libertad: «¿República catalana? ¿República española?» En el que se situaba la polémica sobre la ley de Contratos de cultivo en «el terreno de las componendas políticas», en el que ellos no iban a tomar parte; como tampoco lo iban a hacer en «la proclamación de la independencia de Cataluña ni en el del triunfo de la autoridad de Madrid». El editorial dejaba clara su esencia anarquista e internacionalista: «¿República catalana? ¿República española? ¡No!, Comunismo Libertario, Iberia Libre. ¿Reducir las fronteras de la jaula nacional? No, ensancharlas, más allá de Cataluña, más allá de España, más allá de Iberia entera, hasta llegar a la Confederación universal de pueblos libres» ${ }^{53}$. Ideología que, obligatoriamente, les llevaba a tener, también, una visión diferente sobre la entrada de la CEDA en el gobierno. Según su interpretación, la experiencia de los últimos años republicanos les había reafirmado en que todos los gobernantes «son iguales en la persecución del proletariado, todos son fascistas cuando de defender los privilegios se trata...». Por lo que ante el movimiento que se avecinaba, la CNT recomendaba que nadie se prestase «a servir de juguete» en manos de los políticos ${ }^{54}$. Era evidente que la CNT no podía compartir objetivo con aquellos que, en octubre, dieron un sesgo fundamentalmente nacionalista al levantamiento.

Por su parte, Largo Caballero se desplazó a Cataluña, en febrero del 34, y sancionó la Alianza Obrera catalana constituida a finales del año anterior. El líder ugetista pretendía conseguir paliar la debilidad de su organización en Cataluña. La alianza, formada por la UGT, el Bloque Obrero y Campesino, Izquierda Comunista, la Unión de Socialistas de Cataluña, la Unión de Rabassaires y los Sindicatos de Oposición, no logró atraerse a la CNT, cuestión fundamental si se pretendía una movilización popular ${ }^{55}$. Así que en la madrugada del 5 de octubre, cuando se declaró la huelga general en Cataluña, el

52 GIL PECHARROMÁN, 2006: 301-306.

53 Tierra y Libertad, 30 de junio de 1934.

54 Solidaridad Obrera, 3 de octubre de 1934, en BRADEMAS, 1974: 142.

55 BIZCARRONDO, 2008: 116-7. BRADEMAS, 1974: 123. 
movimiento, según los confederales, era una lucha que había que situarla en el plano nacionalista, carente de masas y del proletariado e impuesta por las pistolas y fusiles de los «escamots», milicia del Estat Catalá. Esta situación no impidió, como sucedió en otros lugares de España, que muchos anarquistas se lanzaran a la calle e intentaran dar al levantamiento un carácter libertario. Según fuentes oficiales, en los pueblos de Montbrio, Monferri, Salomo y Lidemolins, los revolucionarios se habían apoderado de los ayuntamientos y habían declarado el comunismo libertario. En San Sadurní, la FAI se había adueñado del pueblo, mientras que en Villafranca los anarquistas habían quemado tres iglesias y dirigido su ira contra locales del Partido Radical, la Lliga y el Casino Católico ${ }^{56}$.

Según la CNT, sus militantes mantenían un enfrentamiento a doble banda; por un lado, contra catalanistas y miembros de la Alianza; y, por otro lado, contra las fuerzas armadas gubernamentales. En un primer momento, los cenetistas se dirigieron hacía sus sindicatos cerrados desde la última insurrección de diciembre y los abrieron. Pero las fuerzas de la Generalidad los detuvieron y volvieron a clausurarlos. Mientras, en lugares como Lérida, la Alianza declaró la huelga general y el servicio ferroviario quedó interrumpido. Cuando los jefes ferroviarios requirieron fuerzas a la Generalidad para mantener el servicio, se les comunicó la imposibilidad de enviarlas. Circunstancia que indicaba, según los libertarios, que las fuerzas políticas que controlaban el gobierno catalán estaban detrás del movimiento. Al mismo tiempo, representantes de las Juventudes Socialistas y del Bloque Obrero y Campesino arengaban al pueblo sobre el peligro que corrían las libertades catalanas y la deriva fascista del gobierno central. Aunque hubo contactos entre miembros de la CNT-FAI y la Alianza, el entendimiento fue imposible. Así que mientras Companys proclamaba «el Estado Catalán, en la República Federal Española», el periódico confederal Solidaridad Obrera era prohibido, los cenetistas perseguidos y sus locales clausurados. El Comité Regional de la CNT sacaba una hoja clandestina en la que señalaba que no se renunciaba a tomar parte en la acción pero siempre en la forma que correspondía «a sus principios revolucionarios y anárquicos» ${ }^{57}$.

En definitiva, la CNT no participó en el movimiento catalanista, ni en la huelga general promovida desde la Alianza con el beneplácito del gobierno catalán, con lo que ambas acciones estuvieron condenadas al fracaso al faltarles el apoyo de las masas trabajadoras. Así que la intervención de las fuerzas armadas de la $4^{\text {a }}$ División, al mando del General Batet, sofocaron la rebelión en pocas horas. Las fuerzas gubernamentales ocuparon los edificios principa-

56 Informe sobre Cataluña, octubre de 1934, AGMA, Antecedentes políticos, leg. 4, carp. 1.

57 Informe Federación Local de Sindicatos Únicos de Lérida, IIHS, CNT, 68 A. Manifiesto Comité Regional de Cataluña, 6 de octubre de 1934, en PEIRATS, 1971, vol. 1: 101-102. 
les como el Ayuntamiento o el Palacio de la Generalidad, al tiempo que Companys, con el alcalde de Barcelona, Carlos Pi y Suñer, sus consejeros y concejales eran detenidos y trasladados al vapor Uruguay; salvo el Consejero de Gobernación, Josep Dencàs, al que muchos señalaban como responsable de la represión cenetista, que se escapaba por un túnel que comunicaba con el alcantarillado de la ciudad ${ }^{58}$. Huida más que simbólica para un «golpe aparentemente insurreccional» que desde las filas anarquistas se veía como una coartada que escondía la incompetencia de los hombres de Esquerra para solucionar los problemas de Cataluña, por lo que «se optó por una caída heroica, que en lugar de heroica resultó enormemente ridícula» ${ }^{59}$.

Aunque los responsables de la CNT en Cataluña tampoco brillaron en el desenlace de una actuación que, si no de ridícula, podría calificarse de auténtico despropósito. En la noche del lunes, 8 de octubre, los comités regional y local no sólo dieron por terminada una huelga que no habían convocado, sino que lo hicieron desde los micrófonos de la radio instalada en el Cuartel General de la $4^{\text {a }}$ División. Por más que se quisiera justificar que la «desconvocatoria» se hacía «para evitar sacrificios estériles», ante la falta de noticias de Asturias o la poca resistencia de Madrid ${ }^{60}$, lo cierto era que los dirigentes de la organización en Cataluña estaban en contra de este movimiento; por un lado, por el carácter político y nacionalista del levantamiento que protagonizaban, precisamente, aquellos que dirigían la represión contra la CNT en esta región; por otro lado, por los mismos motivos señalados para el caso de Madrid: rencor hacia los socialistas, movimiento ajeno... No en vano, la regional catalana había encabezado la oposición a cualquier aproximación a los socialistas, y se había mostrado intransigente en su negativa a aceptar cualquier tipo de alianza.

Las críticas contra los comités responsables arreciaron y obligaron a su dimisión. Aunque la FAI señalaba que entre las lecciones que había sacado del movimiento estaba, más allá de organizaciones o tácticas, la necesidad de «poseer una estación de radio» ${ }^{61}$. Claro que, como señaló el propio Ascaso, todo hubiese cambiado si se hubiera sabido lo que estaba pasando en Asturias. Lo que quizá no se había parado a pensar el secretario catalán era que, precisamente, la regional asturiana había transitado por un camino opuesto a su regional. Camino que le supuso la crítica y el enfrentamiento con la inmensa mayoría de la organización y que había colocado a los cenetistas astu-

58 Informe sobre Cataluña, AGMA. Antecedentes políticos, leg. 4, carp. 1. David Ruiz, p. 131.

59 Tiempos Nuevos, II/1, 10 de enero de 1935.

60 Tiempos Nuevos, II/1, 10 de enero de 1935.

${ }^{61}$ Carta Comité Peninsular de FAI, Barcelona, al Comité de Relaciones de Grupos Anarquistas de Lengua Española en Francia, 27 de octubre de 1934, IIHS, Fondo FAI, sig. 4.1-18. 
rianos, prácticamente, en la disidencia. Sin embargo, ese camino, tan criticado por faístas y anarquistas, les había conducido allí a dónde ellos querían llegar, pero no habían sido capaces de llevar a la CNT.

\section{LA CNT EN ASTURIAS: ALIANZA Y REVOLUCIÓN}

La situación en la regional asturiana, a principios de 1934, a pesar de ser delicada no era tan grave como en otras regionales de la $\mathrm{CNT}^{62}$. En gran medida por su actuación limitada en el movimiento insurreccional de diciembre del 33. El comité regional había percibido la precipitación con que se preparaba el levantamiento y aplazó el inicio de la acción hasta el lunes 11 de diciembre, cuando el movimiento había comenzado el viernes anterior. El alcance fue dispar: prácticamente nulo allí donde la presencia confederal era minoritaria, como Oviedo, e importante donde era mayoritaria, como Gijón. La represión, aunque dura, no llegó a los extremos de Aragón, mucho más implicada en el movimiento ${ }^{63}$.

Los cenetistas asturianos encarcelados en la prisión del Coto publicaron un documento en el que apoyaban la constitución de una alianza obrera. Habían llegado a la conclusión de que la CNT no se bastaba, por sí sola, para alcanzar la revolución. Era necesaria, como demostraban los fracasos de los últimos movimientos, la colaboración de otras fuerzas de izquierdas, principalmente de la $\mathrm{UGT}^{64}$. No era la primera vez que la regional asturiana mantenía esta posición, Eleuterio Quintanilla, en el Congreso de 1919, defendió la unión con la UGT, proposición que fue derrotada por otra que abogaba por su simple y llana absorción. Ahora los faístas volvían a mostrar una fuerte resistencia a la alianza. En el pleno nacional de febrero de 1934, la discusión «tomó caracteres de inusitada violencia», y el tono «se elevó más allá de los límites que el sentido de la reflexión y la prudencia aconsejaban ${ }^{65}$. Sin embargo, la regional asturiana hizo caso omiso de advertencias y acuerdos confederales, y firmó la alianza con UGT en Gijón, el 28 de marzo, al que se unió en el mismo acto la Federación Socialista Asturiana. El objetivo era el triunfo de la revolución social, estableciendo un régimen fundado sobre principios socialistas federativos.

62 Para la CNT en Asturias: BARRIO, 1988: 360-402.

63 Acta Pleno Nacional de Regionales, 10 de febrero de 1934, IIHS, CNT, 93 B.

64 Documento firmado por Avelino González Mallada, A. Bartolomé, Segundo Blanco, Horacio Argüelles, José D. Doraño, Avelino Martínez, Pelayo Cifuentes y José Ma Martínez en la cárcel del Coto, 26 de enero de 1934, IIHS, Fondo Ramón Álvarez, caja 443. BARRIO, 31 (Madrid, 1984): 123-129.

65 Informe Comité Nacional de CNT al Secretariado Internacional de la AIT, 30 de julio de 1935, IIHS, sig. CNT, 50 A. 
Para conseguir este fin se constituirían comités de ambas formaciones que irían desde el local al nacional, al tiempo que se proponía el cese de cualquier campaña de propaganda que pudiera entorpecer la marcha de la alianza ${ }^{66}$.

Lo cierto es que la regional asturiana actuó de tal forma que anduvo en el filo de la disidencia en todo este período. Hasta el punto que cuando la organización confederal debatió la firma del pacto en el pleno de junio, la delegación asturiana, compuesta por José M Martínez y Ramón Álvarez «Ramonín», tuvo que señalar, en primer lugar, que seguía perteneciendo a la CNT. La principal oposición vino por parte de la delegación catalana, formada por Durruti y Ascaso ${ }^{67}$, que mantuvieron las críticas contra los socialistas y defendieron que de haber continuado con el «criterio absorcionista», aprobado en 1919, se estaría en condiciones de atraer a sus elementos revolucionarios. El pleno censuró la actuación de Asturias, pero como no tenía capacidad de decisión en asunto tan espinoso, acordó celebrar en los próximos dos meses una conferencia nacional de sindicatos ${ }^{68}$.

Es evidente que el tema de la alianza dividía peligrosamente a la CNT. De hecho, cuando el comité regional presentó su gestión ante la organización asturiana, 39 sindicatos lo aprobaron, 35 lo rechazaron y hubo 4 abstenciones $^{69}$. Las reticencias hacia los socialistas estaban en la base de la discusión y amenazaban con llevar al traste la reciente alianza. Así que para que la confraternización fuera un hecho fue necesaria la presencia real del enemigo. Ésta vino con la convocatoria de Gil Robles de un acto en el santuario de Covadonga, el 9 de septiembre. Concentración que se interpretaba como el inicio de una nueva reconquista, aunque esta vez fuera contra los propios españoles, eso sí, militantes de fuerzas de izquierda. Aunque el acto logró congregar a cerca de 6.000 personas, la huelga general dirigida por la Alianza fue un auténtico éxito y consiguió la unidad de acción de los militantes de ambas organizaciones. Otros grupos, como los comunistas, vieron la importancia de la unión y cambiaron su actitud crítica hacia la Alianza. Así que solicitaron el ingreso de su sindicato, la Confederación General del Trabajo Unitaria (CGTU). Sin embargo, el comité aliancista no admitió su inclusión inmediatamente, en gran media para asegurarse de la «seriedad de tan brusca conversión». Así que el 5 de octubre, fecha de inicio de la insurrección, la CGTU no formaba todavía parte de ella ${ }^{70}$.

66 Pacto en Asturias entre CNT y UGT, 28 de marzo de 1934, IIHS, CNT, 68 A.

67 Notas de Ramón Álvarez sobre el pleno, IIHS, Fondo Ramón Álvarez, caja 449.

68 Actas Pleno Nacional de Regionales, Madrid, junio de 1934, IIHS, FAI, 36 B.

69 Actas Pleno Regional de Asturias, León y Palencia, 16 de septiembre de 1934, IIHS, Fondo Ramón Álvarez, caja 431.

70 Carta de Avelino González Entrialgo, Mérida (Venezuela), a Ramón Álvarez, París, 19 de enero de 1975, IIHS, Fondo Ramón Álvarez, caja 384. 
La Alianza constituida en Asturias marcó un elemento diferenciador con respecto al resto de España. La participación de la CNT, en unión a la UGT, imprimió un carácter revolucionario al movimiento en Asturias, lo que a la postre lo convirtió en el referente de los sucesos de octubre. Unidad a la que, hay que recordar una vez más, eran contrarios los dirigentes de las dos principales formaciones. Aunque otras circunstancias fueron importantes para que el levantamiento tuviera una importancia excepcional en Asturias; como la situación extrema que vivían mineros y metalúrgicos, ante el cierre de minas y fábricas. Consecuencia, en gran medida, de la importante crisis económica, pero también de la actitud de los dueños de las explotaciones que, si ya en el primer bienio no respetaron la legislación laboral, ahora, con la llegada de la derecha al poder, endurecían su posición. El incremento del paro, la falta de ayuda imprescindible para las familias y un futuro incierto convirtieron a la región en un lugar propicio para el levantamiento ${ }^{71}$. Un ejemplo ilustrativo es lo sucedido en La Felguera, núcleo del concejo de Langreo. La Felguera era un centro industrial del Valle del Nalón, donde se encontraba la compañía sidero-metalúrgica Duro-Felguera, con una presencia mayoritaria de afiliados a la CNT entre sus trabajadores. La compañía había sufrido drásticas reducciones de plantilla, pasando de más de 2.300 empleados a cerca de 1.900 . Los trabajadores respondieron con importantes huelgas a los despidos, como la mantenida desde noviembre de 1932 a agosto de 1933. La situación de la población era insostenible. El ayuntamiento puso en marcha una comisión de beneficencia, que muchas veces estaba desbordada. La necesidad de las familias fomentaba la mano de obra infantil, circunstancia que provocaba el vacío de las aulas. A esta grave situación social se unió la presión política por parte de las fuerzas vencedoras en las elecciones del 33. En el ayuntamiento de Langreo, los concejales socialistas y radical-socialistas pedían, el 31 de marzo de 1934, el cese de cacheos y registros a que eran sometidos personas de reconocida fidelidad a la república; el 14 de mayo, denunciaban la intimidación de la que eran objeto por parte del capitán de la Guardia civil Alonso Nart y pedían medidas para preservar de intromisiones su gestión; el 10 septiembre, se denunciaba que había personas reacias a pagar los tributos y que las copias del último padrón de solares había desaparecido; el 15 de septiembre, se acordaba suspender la sesión por la detención del socialista Berlarmino Tomás; en el mismo mes, la minoría comunista denunciaba la agresión de la fuerza pública contra una manifestación y la muerte de un obrero ${ }^{72}$.

A este ambiente político y socialmente caldeado se añadía la entrada de armas. Según un informe oficial, en el puesto de San Esteban de Pravia, en la noche del 10 de septiembre, fuerzas de la guardia civil y carabineros, al man-

71 RUIZ, 2008: 233-235.

72 Archivo del Ayuntamiento de Langreo, IIHS, Fondo Ramón Álvarez, caja 444. 
do del sargento Ferreiros Preire, «aprehendieron 70 cajas de munición de fusil que alijaba el vapor Turquesa, dándose a la fuga otros camiones cargados de armas $\rangle^{73}$. A pesar de alijos como éste y otros encontrados en Madrid ${ }^{74}$, las armas que tenían los insurrectos a principios de octubre no parecen considerables. El propio Azaña, en la sesión parlamentaria que intentaba implicarle en el asunto del Turquesa, destacó que era «una fantasía el pensar que se puede hacer una revolución con 500 máuseres y 24 ametralladoras (carga del Turquesa). Esto no lo puede decir un parlamento serio» ${ }^{75}$. Ni lo podían defender los dirigentes socialistas que llevaban meses preparando el movimiento. Lo que pone en entredicho que las pretensiones socialistas, más allá del discurso político, fueran las de una auténtica revolución ${ }^{76}$; sino, más bien, una huelga general en buena parte de España con levantamientos armados en lugares señalados, que obligaran al presidente de la República al cambio de gobierno o la convocatoria de nuevas elecciones. Porque si hubiese sido un movimiento revolucionario, resulta incomprensible que formando parte del gobierno que reprimió la insurrección de enero de 1933 y viendo como el nuevo ejecutivo conservador hizo lo propio con la de diciembre del mismo año, no extrajeran conclusiones y cometieran errores de bulto similares a los anarquistas; entre otros, realizar el levantamiento en solitario, sin armas suficientes y sin la colaboración de los que las tenían: las fuerzas armadas, que habían reprimido sin contemplaciones cualquier levantamiento. A lo que habría que añadir la ausencia de sus líderes en momentos claves, como sucedió en Madrid.

De todas formas, cualquier objetivo quedó superado en Asturias, donde el impulso de los dirigentes locales terminó por atomizar el movimiento y difuminó el control socialista. Según los revolucionarios ocupaban pueblos y ciudades de Asturias se constituían comités que tenían una orientación relacionada con la organización mayoritaria en la localidad. Así, la CNT, que contaba en la región con unos 22.000 afiliados, tuvo sus bastiones principales en Gijón y La Felguera. Avelino González Entrialgo, cenetista asturiano que tuvo una actuación destacada tanto en la formación de la Alianza como en los acontecimientos de Gijón, señaló en un informe que la principal preocupación era la falta de armas, pues tan sólo contaba con unos 120 fusiles y 3.000 cartuchos. Los requerimientos para que se enviaran armas desde Oviedo fueron

73 La fecha que aparece en el informe es el 11 de septiembre, confusión que, seguramente, se debe a que la operación tuvo lugar en la noche del 10 al 11, Memoria Comandancia de Asturias, AEHGC.

$74 A B C, 29$ de septiembre de 1934. Véase también: BIZCARRONDO, 2008: 120-121. RUIZ, 2008: 122-123.

75 La Vanguardia, 21 de marzo de 1935.

76 AVILÉS, 20 (Madrid, 2008): 129-158. 
continuos, pero infructuosos. De hecho, esta circunstancia retrasó el estallido de la insurrección en Gijón hasta la noche del día 6, cuando ante las noticias de que Oviedo era «un volcán revolucionario» y que «la cuenca minera era ya del pueblo trabajador», se decidió avanzar hacia la ciudad. En las fuerzas había preeminencia de CNT, luego ugetistas y, por último, comunistas de la CGTU. Entrialgo apunta que, aunque la dirección de los grupos quedó en mano de los militantes más comprometidos, «la mayoría eran compañeros que figurando en la CNT no era corriente verlos significarse como idealistas $»{ }^{77}$. Dato revelador que vislumbra una participación mucho más popular que en insurrecciones anteriores, y que los más concienciados supieron derivar hacia un estadio revolucionario. Porque lo sucedido en Asturias fue mucho más que un levantamiento provocado por un malestar generalizado, como solía suceder en esos estallidos de violencia que, esporádicamente, recorrían los campos de España. Lo que sucedió fue un movimiento insurreccional, entendido como un primer paso necesario y obligatoriamente violento, que tenía como finalidad la consecución de la revolución social. Por lo menos en ese sentido lo enfocaron los cenetistas que avanzaban por los barrios gijoneses cumpliendo el carácter violento de la insurrección, para tras la destrucción proceder a la obra constructiva de la revolución. Así que a la toma de edificios a sangre y fuego, le siguió la formación de comités de barriada y abastecimiento para evitar saqueos y suministrar víveres a la población. Medidas que eran imprescindibles «puesto que de la organización bien orientada y enérgica contra los que pretendieran aprovecharse del confusionismo dependía en parte la simpatía de todos los ciudadanos liberales hacia el movimiento». Cómo sucedió con un delincuente apodado el «Biribí», que tras el robo en una casa fue detenido y enviado al frente de combate, a pesar de que más de uno quería fusilarle ${ }^{78}$.

El otro centro cenetista por excelencia era La Felguera. Los militantes de esta localidad se habían significado por su oposición a la Alianza. Sin embargo, al estallar el movimiento insurreccional, hicieron bueno lo tantas veces repetido desde las filas anarquistas: se echaron a la calle. Los socialistas no habían contado con ellos pero, según señaló uno de los militantes cenetista, olvidaron «recientes agravios», empuñaron las armas y sitiaron el cuartel de la Guardia civil, que terminó siendo tomado a dinamita y fusil. Otros grupos de hombres y mujeres del pueblo «constituyeron un torrente insurreccional único», que ocupaba los edificios públicos, el convento de los dominicos, se

77 Cartas de Avelino González Entrialgo, Mérida (Venezuela) a Manuel Pérez Covián y Ramón Álvarez, París; Informe de Avelino González Entrialgo, Gijón, 25 de octubre de 1934, ambos en IIHS, Fondo Ramón Álvarez, caja 384.

78 Informe de Avelino González Entrialgo, Gijón, 25 de octubre de 1934, IIHS. Fondo Ramón Álvarez, caja 385. 
adueñaba del ayuntamiento, incendiaba «los archivos del registro» y hacía ondear «la bandera roja y negra»; para a continuación dirigirse a la iglesia que, rociada con gasolina e incendiada, «quedó totalmente destruida». Al igual que en otras localidades asturianas, los revolucionarios constituyeron un comité revolucionario, que mandó ocupar y mantener activo el complejo sidero-metalúrgico de Duro-Felguera. Se detuvo a su director general y a los demás ingenieros de la compañía, al tiempo que se organizaban brigadas en cada uno de los talleres. La fábrica estuvo en funcionamiento durante el tiempo que duró la revolución. De aquí salieron, hacia otros lugares de Asturias, camiones blindados con chapas para protegerse del fuego de las ametralladoras.

La revolución en La Felguera tuvo unas características especiales. El comité revolucionario publicó un manifiesto en el que proclamó la revolución social, pero convocó a los ciudadanos a una asamblea popular en el parque de la población con el objetivo de elegir el régimen social a construir. Aunque, con la fuerte presencia cenetista y la vorágine de los recientes acontecimientos, éste no podía ser otro que el comunismo libertario. En consecuencia, se abolió el dinero y se constituyó un comité de abastecimiento que, mediante vales, atendió las necesidades de la población. Otra característica especial de La Felguera fue el carácter hasta cierto punto pacífico de la revolución, más allá de los muertos en la lucha del movimiento insurreccional. No hubo represalias ni asesinatos como sucediera en otras localidades, circunstancia señalada de forma significativa por los cenetistas. Como lo sucedido en Sama de Langreo, con mayoría socialista. Mientras que en La Felguera hubo dos muertos de las fuerzas del orden, en Sama hubo 69. Aunque es cierto que la situación en esta localidad antes de la insurrección era de mayor enfrentamiento, y que tanto el contingente de las fuerzas armadas y la resistencia que opusieron fue mayor, no dejaron de suceder actos de extrema violencia como el fusilamiento de 22 guardias tras su rendición ${ }^{79}$.

La situación revolucionaria remitió desde el 10 de octubre, día en la que llegaban noticias del desembarco del ejército. La falta de acción en el resto de España facilitaba el envío de fuerzas. Aunque, al día siguiente, las comandancias de toda España señalaban la vuelta a la normalidad en la inmensa mayoría de las provincias, en Asturias continuaba la lucha, y el propio General Ochoa manifestaba que avanzaba con gran dificultad ${ }^{80}$. Con el avance del ejército y las consabidas represalias que se avecinaban, llegaba la orden de retirada. Fueron momentos de desconcierto y desesperación, pero también de enfrentamientos entre las fuerzas revolucionarias, con cambios en los comités y

79 «La Felguera en la revolución asturiana de 1934», documento editado por CNT, Francia 1973, IIHS, Fondo Ramón Álvarez, caja 443. RUIZ, 2008: 293-297.

80 Estado Mayor Central, Servicio de Información, AGMA, Antecedentes políticos, leg. 4, carp. 2 . 
acusaciones de traición. Como sucedió con el cenetista José $\mathrm{M}^{\mathrm{a}}$ Martínez, principal impulsor de la alianza obrera en Asturias, al que el comité revolucionario de Oviedo le encargó llevar la orden de retirada a los pueblos. Esta circunstancia supuso que, aquellos que se negaban a admitir la derrota, vieran en su acción un acto de traición. Así que cuando Martínez apareció muerto en Sotiello, muchos cenetistas no dejaron de ver la mano de los socialistas tras su supuesto asesinato. Aunque, en realidad, murió por el disparo fortuito de su propia pistola mientras la limpiaba ${ }^{81}$.

Metáfora de un movimiento tan confuso como variado, y por el que Asturias, en su soledad revolucionaria, iba a pagar un alto precio. Miles de personas huían de sus poblaciones y los que podían salían de España. Era el punto y seguido de una insurrección, con la consiguiente represión, que supuso la muerte de más de 1.000 personas y cerca de 40.000 encarcelados; y que en los meses siguientes se completaría con la expulsión de miles de trabajadores de sus tajos.

\section{CONCLUSIONES}

Los sucesos de octubre del 34 no pueden considerarse, en líneas generales, como un movimiento revolucionario. Habría que hablar de acciones diversas: huelgas, levantamientos, movimientos nacionalistas... y, en el caso de Asturias, una insurrección que alcanzó el estadio revolucionario por un corto espacio de tiempo.

En cuanto a la CNT, las críticas a nivel nacional e internacional por su actuación fueron muy duras. El argumento principal era que la organización confederal no podía faltar a la cita con la revolución, independientemente de quien la iniciara. Con mayor motivo cuando en los plenos confederales se había repetido hasta la saciedad que si los socialistas querían la revolución sólo tenían que salir a la calle, donde encontrarían a la CNT. Pero los anarquistas, que dirigían la organización, se vieron atrapados entre el discurso retador y la animadversión hacia aquellos que protagonizaban el levantamiento. Un levantamiento que, en la mayoría de los casos, se sentía como ajeno, tanto por unos objetivos difusos, como por su postergación en la organización y puesta en marcha de la acción.

Estas circunstancias y la importante diversidad que siempre ha acompañado al movimiento libertario fueron determinantes para que la actuación de la CNT fuera variopinta y estuviera presidida por la desorientación. Porque

81 Tiempos Nuevos, 4 de abril de 1935, advertía de la falsedad del asesinato de Martínez. La versión final la aportó el periodista e investigador Paco Ignacio Taibo, La Voz de Asturias, 29 de octubre de 1981. 
mientras había militantes que secundaban huelgas y levantamientos llevados por su conciencia de clase, los responsables confederales mostraban su división entre los que estaban dispuestos a olvidar recientes afrentas socialistas y participar en la acción; y aquellos que no querían colaborar en un movimiento que no sólo no era el suyo, sino que lo protagonizaban los que, según interpretaban, eran los responsables de la desastrosa situación por la que atravesaba la CNT. En este maremágnum, la dirección confederal se quedó sin respuestas.

El prestigio revolucionario de la CNT estaba herido. Aunque la actuación de la regional asturiana iba a salvar, irónicamente, el honor confederal. Digo irónicamente porque los cenetistas asturianos llevaron una línea completamente opuesta a la defendida por la dirección confederal hasta límites que rondaron la ruptura. Su firma de la Alianza Obrera con la UGT, en contra de la mayoría de la organización, y su participación en el movimiento insurreccional, sin esperar las consignas del comité nacional, les colocaron en franca rebeldía. Sin embargo, estas actuaciones se convirtieron en el gran ejemplo a seguir en tiempos venideros. A lo que no fue ajeno la solución que el gobierno conservador dio al conflicto, tanto por el envío de unas fuerzas que recordaban en exceso a un ejército colonial, como por la represión excesivamente cruenta e ilegal que realizaron los que deberían haber restablecido el imperio de la ley y no el de la venganza. La mezcla de autoritarismo y torpeza del gobierno, ignorando actuaciones ilegales y avalando la expulsión de miles de trabajadores de sus trabajos, ayudó a la izquierda, en los meses siguientes, a hacer del fracaso un triunfo y señalar como objetivo prioritario la unidad, que se vería concretada en la formación del Frente Popular. Para la CNT se abrían «viejas» e inquietantes decisiones. Por un lado, el acuerdo con los Sindicatos de Oposición y la UGT se veían, tras la experiencia asturiana, como el único camino posible hacia la revolución; por otro lado, la organización tendría que replantearse, una vez más, cuestiones significativas, como su actitud abstencionista ante las futuras elecciones. A ello le obligaban los miles de presos confederales que abarrotaban las cárceles republicanas.

\section{Bibliografía}

Avilés, Juan, «Los socialistas y la insurrección de octubre de 1934», Espacio, tiempo y forma, Historia Contemporánea, 20 (2008), 129-157.

Azaña, Manuel, Memorias políticas y de guerra, vol. 1, Barcelona, Crítica, 1981.

Barrio, Ángeles, «La CNT de Asturias, León y Palencia y la Alianza Obrera de 1934», Estudios de Historia Social, 31 (1984), 123-129.

Barrio, Ángeles, Anarquismo y anarcosindicalismo en Asturias (1890-1936), Madrid, Siglo XXI, 1988. 
Borderías, Cristina y Vilanova, Mercedes, «Cronología de una insurrección: Figols en 1932», Estudios de Historia Social, 24-25 (Madrid, 1983), 187-199.

Bizcarrondo, Marta, Historia de la UGT. Entre la democracia y la revolución, 19311936, Madrid, Siglo XXI, 2008.

Brademas, John, Anarcosindicalismo y revolución en España (1930-1937), Barcelona, Ariel, 1974.

Casanova, Julián, De la calle al frente. El anarcosindicalismo en España (19311939), Madrid, Crítica, 1997

Elorza, Antonio, La utopia anarquista durante la guerra civil española, Madrid, Ayuso, 1973.

García Oliver, Juan, El eco de los pasos, Barcelona, BackList, 2008.

Gil Pecharromán, Julio, Segunda República Española (1931-1936), Madrid, Biblioteca Nueva, 2006.

Herrerín, Ángel, Anarquía, dinamita y revolución social. Violencia y represión en la España de entre siglos (1868-1909), Madrid, Los libros de la catarata, 2011.

Juliá, Santos, Madrid, 1931-1934: de la fiesta popular a la lucha de clases, Madrid, Siglo XXI, 1984.

Lorenzo, César M., Los anarquistas españoles y el poder, París, Ruedo Ibérico, 1969.

Navarro, Javier, «Diversidad y dualismo. La(s) cultura(s) política(s) del movimiento libertario español», en Bosch, Aurora, Carnero, Teresa y Valero, Sergio (eds.), Entre la reforma y la revolución. La construcción de la democracia desde la izquierda, Granada, Comares, 2013.

Paniagua, Xavier, La sociedad libertaria. Agrarismo e industrialización en el anarquismo español, 1930-1939, Barcelona, Crítica, 1982.

Peirats, José, La CNT en la revolución española, vol. 1, Cary-Colombes, Ruedo Ibérico, 1971.

Ramos, Tano, Casas Viejas: crónica de una insidia (1933-1936), Barcelona, Tusquets, 2012.

Ruiz, David, Octubre de 1934. Revolución en la República española, Madrid, Síntesis, 2008.

Souto, Sandra, $Y$ ¿Madrid? ¿Qué hace Madrid?: movimiento revolucionario y acción colectiva (1933-1936), Madrid, Siglo XXI, 2004.

Vega, Eulalia, Anarquistas y sindicalistas durante la Segunda República. La CNT y los Sindicatos de Oposición en el País Valenciano, Valencia, Edicions Alfons el Magnànim, 1987.

Vega, Eulalia, El treintisme a Catalunya: divergències ideològiques en la CNT (1930-1933), Barcelona, Curial Edicions Catalans, 1980.

Villa García, Roberto, «La CNT contra la república: La insurrección revolucionaria de diciembre de 1933», Historia y Política, 5 (2011), 177-205.

Recibido: 04/10/2013

Aceptado: 07/07/2014 